\title{
Sustainable housing in the Russian regions
}

\author{
A'fis Farkhutdinov ${ }^{1,}$, Sergey Gots $^{2}$, Klara Yamaletdinova $^{3}$, Vadim Andreyev ${ }^{4}$, and Zemfira \\ Yangurazova $^{2}$ \\ ${ }^{1}$ Ufa state petroleum technological university, 1, Kosmonavtov str., 450062, Ufa, Russia \\ ${ }^{2}$ Bashkir State University, 32, Zaki Validi str., 450076, Ufa, Russia \\ ${ }^{3}$ Chelyabinsk State University, Chelyabinsk, Russia \\ ${ }^{4}$ State Autonomous Scientific Department Institute of Oil and Gas Technologies and New Materials, \\ 129/3, pr. Oktyabtya, 450075, Ufa, Russia
}

\begin{abstract}
Social living conditions and related problems are one of the key indicators of the level and rate of socio-economic development of modern society. The housing problem is characterized by several indicators: the housing deficit (quantitative indicator); high cost of housing (financial indicator); the incompatibility of the structure of the housing stock to the demographic structure of families (structural indicator); the incompatibility of existing housing stock requirements to consumer housing quality (quality indicator); the incompatibility of the requirements to maintenance condition of the housing stock (operational indicator); location of housing (infrastructure, environmental and logistics indicators). The purpose of this study is to analyze and highlight the degree of influence of the main factors on the quantitative indicators of the housing problem based on statistical data over the past few years. A statistical analysis of the impact of various factors on the price of housing in three regions of the Russian Federation is conducted. It is established that the main factor influencing the price of housing is the average per capita income of the population.
\end{abstract}

\section{Introduction}

Social living conditions and related problems are one of the key indicators of the level and pace of socio-economic development of modern society. The housing problem is characterized by several indicators: the housing deficit (quantitative indicator); high cost of housing (financial indicator); the incompatibility of the structure of the housing stock to the demographic structure of families (structural indicator); the incompatibility of existing housing stock requirements to consumer housing quality (quality indicator); the incompatibility of the requirements to maintenance condition of the housing stock (operational indicator); location of housing (infrastructure, environmental and logistics indicators).

The purpose of this study is to analyze and highlight the degree of influence of the main factors on the quantitative indicators of the housing problem based on statistical data over the past few years.

\footnotetext{
*Corresponding author: nur125@yandex.ru
} 


\section{Materials and methods}

The first of the main factors that directly affect the housing problem is the demographic indicators of population change. Consider the statistics for of the Russian Federation on population changes from 2005 to 2018. According to the indicators of the Federal state statistics service, there is an annual increase in the share of the urban population of the Russian Federation and a decrease in the number of rural residents. The total population in 2012 was 143.2 million people, and in 2018 it reached 146.8 million people, i.e. increase in the population by 3.6 million people. The population growth was associated with two main factors: natural population growth (about 1 million people); and a jump in the population in 2014 associated with the incorporating of the territory of the Crimean Federal district (about 2.6 million people). From 2012 to 2018, the urban population increased by approximately 3.4 million people, while the rural population increased by approximately 0.17 million people. From 2005 to 2018, the number of urban residents increased by 4.39 million people, and in rural areas decrease of 1.07 million people.

It is also interesting to study the regional features of the impact of the above factors of population change on the housing problem. To analyze the above regional features, three regions were selected in this paper: the Republic of Bashkortostan, Chelyabinsk Region, Perm Region.

Bashkortostan is one of the leading industrial and agricultural regions of the Russian Federation. The Republic of Bashkortostan is one of the main oil producing regions of the country, the center of the chemical industry and machinery manufacturing.

Table 1 shows that from 2012 to 2015 there was an annual increase in the population in the Republic of Bashkortostan, and in 2015-2018 - an annual decrease in the population. In 2014-2016, the total population was about 4.07 million, of which the urban population was 2.51 million and the rural population was 1.56 million.

Chelyabinsk region is an industrial region, one of the most economically developed regions of Russia.

The economy of the Perm region has a multi-industry structure. The branches of industry specialization are the fuel and energy complex, petrochemical industry, machinery manufacturing, forestry, food industry, etc.

The second factor affecting the existence of the housing problem is both the average availability of living space per inhabitant of a particular region, and the existing differences in the availability of housing for different segments of the population, which differ from each other in different financial incomes. The volume and structure of the housing stock in many cities of the country still does not correspond to the demographic structure of the population (figure 1), which significantly worsens the housing conditions of citizens. The lack of progress in solving the housing problem is evidenced by the failure of state programs to provide social housing for certain categories of the population (military personnel, internally displaced persons, etc.). Many families live in communal apartments and dormitories.

One of the main factors in solving the housing problem is the reduction of high housing prices. The authors M. I. Kamenetsky and N. Y. Yaskova [1] consider three components for solving the housing problem:

The first component is the activation of all processes that ensure the effective functioning of the investment and construction sector of the national economy, including the prevention of impoverishment and, as a result, the disappearance of a significant part of construction organizations with their labor and production potential.

The second component is the creation of a new real state housing policy.

The third component is the formation of an almost new material and technical base of the domestic construction complex as a whole (and in the interests of the entire society), 
taking into account the preservation and subsequent strengthening of the position of the national economy in the structure of the world economy.

The formation and regulation of the market value of housing mainly depends on the supply and demand of the population. An increase in the supply of housing reduces demand, and this leads to a decrease in the rate of housing construction.

Average prices in the housing market do not take into account the financial capabilities of low-income segments of the population. However, it is people with low incomes who primarily need to improve their housing conditions. Accordingly, the construction of housing should take into account this category of citizens. For people with low-income, a segment of social housing that is regulated by the state and lies outside the competitive real estate market should be formed in the future. Individuals with above-average incomes are able to finance the purchase of an apartment at their own expense to improve their own housing.

Next, we will try to establish a statistical relationship between average prices in the housing market of the Russian Federation and regions of Russia. To obtain quantitative data, we will find the correlation coefficients using the following formula [8]:

$$
r_{x y}=\frac{n \sum_{i=1}^{n}\left(x_{i} \cdot y_{i}\right)-\sum_{i=1}^{n} x_{i} \cdot \sum_{i=1}^{n} y_{i}}{\sqrt{\left[n \sum_{i=1}^{n} x_{i}^{2}-\left(\sum_{i=1}^{n} x_{i}\right)^{2}\right] \cdot\left[n \sum_{i=1}^{n} y_{i}^{2}-\left(\sum_{i=1}^{n} y_{i}\right)^{2}\right]}}
$$

$\mathrm{r}_{\mathrm{xy}}$ is the correlation coefficient between the indicators $\mathrm{x}$ and $\mathrm{y}$;

$\mathrm{x}_{\mathrm{j}}, \mathrm{y}_{\mathrm{i}}$ are the reference values of the $\mathrm{x}$ and $\mathrm{y}$ indicators for the Russian Federation and one of the three regions of the country, respectively.

$\mathrm{n}$ - number of reference values.

To perform calculations based on correlation analysis we use the correlation tool in MS Excel. As comparable values, we take modified indicators of average prices in the housing market for the Russian Federation and regions. The initial data for calculations are taken from figure 2. The values of the correlation coefficients are located in the range from -1 to +1 . The closer the correlation coefficient is to 1 , the stronger the mutual dependence between the analyzed parameters.

Based on the above calculation results, it can be concluded that, with the exception of crisis periods of development, housing prices change consistently on average across the country and for each of these regions. At the same time, the strongest influence of average prices on the housing market is observed in the Republic Bashkortostan, and the weakest influence is in the Perm Region.

The fourth factor affecting the existence of the housing problem is total income of different segments of the population. Consider the statistical data on the population's income shown in figure 5 [9]. In 2019, the nominal per capita income was: for the Russian Federation - 41 thousand rubles; for the Chelyabinsk Region-28 thousand rubles. For comparison, we note that the average salary in the country for 1983 a year was about 200 rubles a month [3].

\section{Results}

There is a development of housing construction in the Russian Federation, the quality of housing is improving every year, but this is not enough for a comfortable living of citizens. Figure 1 shows that in the Russian Federation in 2018, the total area of housing per inhabitant is 26 square meters, but many families have less than 9 square meters per capita. 


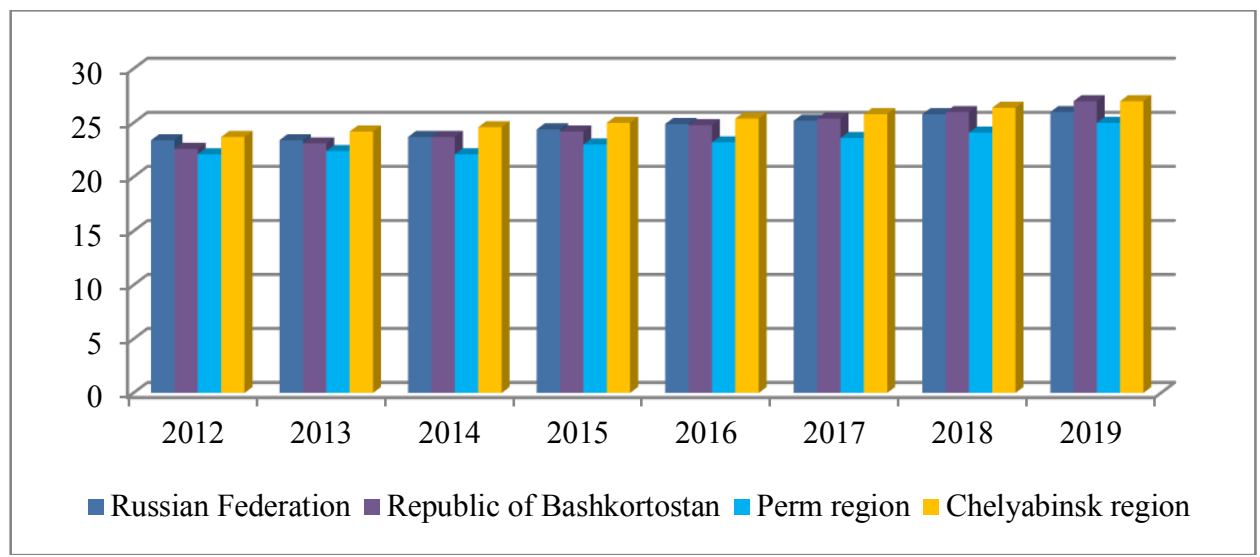

Fig. 1. Total area of residential premises per inhabitant on average, square meter of total area, the value of the indicator for the year.

The third factor affecting the existence of the housing problem is the relatively high housing prices. Today, the main problem of building affordable comfortable housing remains open when prices are very high and they are not available to all residents. For information in 1983 a square meter on average cost 250 rubles across in the country [3]. Statistics on average prices in the housing market for 1 square meter of the total area (figure 2) shows a trend of annual price growth from 2005 to 2019 [4]. Although there are certain exceptions. So, for the periods of 2008-2010 and 2015-2017, there was a decrease in prices in the Chelyabinsk region. However, this reduction in prices was clearly not enough to significantly improve the social conditions for the population of the region.

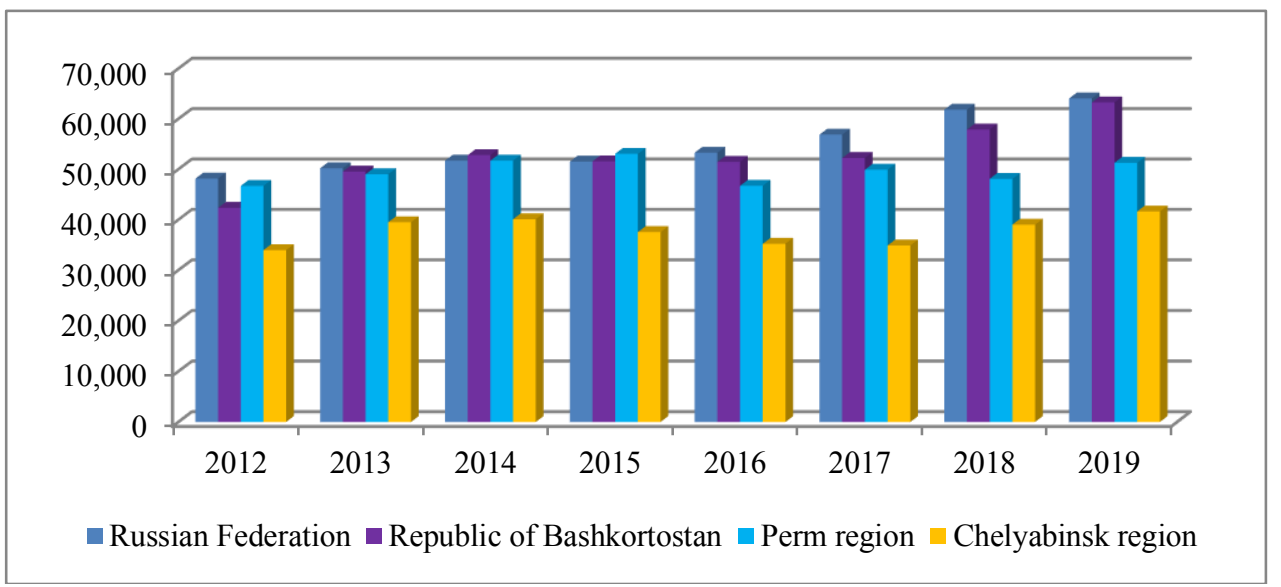

Fig. 2. Average prices on the housing market for 1 square meter of total area, ruble.

As shown in figure 3, the housing market differs in value from the new homes market as in the city of Chelyabinsk [5], and the city of Moscow. The cost of the new homes market in Chelyabinsk is 42,215 rubles per 1 square meter, and in Moscow - 203 thousand rubles per 1 square meter (in 2019 prices). The cost of apartments in St. Petersburg lags behind the cost of apartments in Moscow by 82 thousand rubles. Average prices on the housing market in Perm [6] are 62 thousand rubles per one square meter, which is lower by 23 basis points compared to the same indicators of the city of Ufa. 


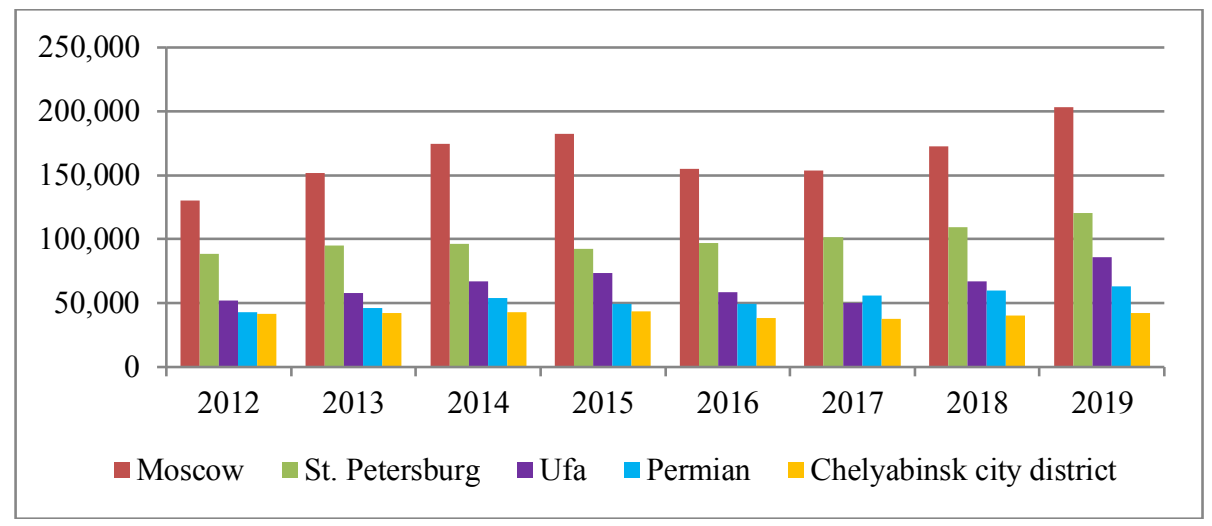

Fig. 3. Average prices for cities on the housing market in rubles per 1 square meter of total area.

As a result of calculations, the following matrix of linear correlation coefficients was obtained:

1) between the Russian Federation and the Republic of Bashkortostan $r_{x y}=0.90$,

2) between the Russian Federation and the Perm Region $r_{x y}=0.86$,

3 ) between the Russian Federation and the Chelyabinsk Region $r_{x y}=0.89$.

Using a polynomial approximation of the distribution of average prices in the housing market within each of the groups identified in official statistical reports, we obtained the trend dependencies shown in figure 4. The approximation did not use the statistics of the crisis years for the Republic of Bashkortostan and the Perm region from 2005 to 2013, and for the Chelyabinsk region - from 2005 to 2014.

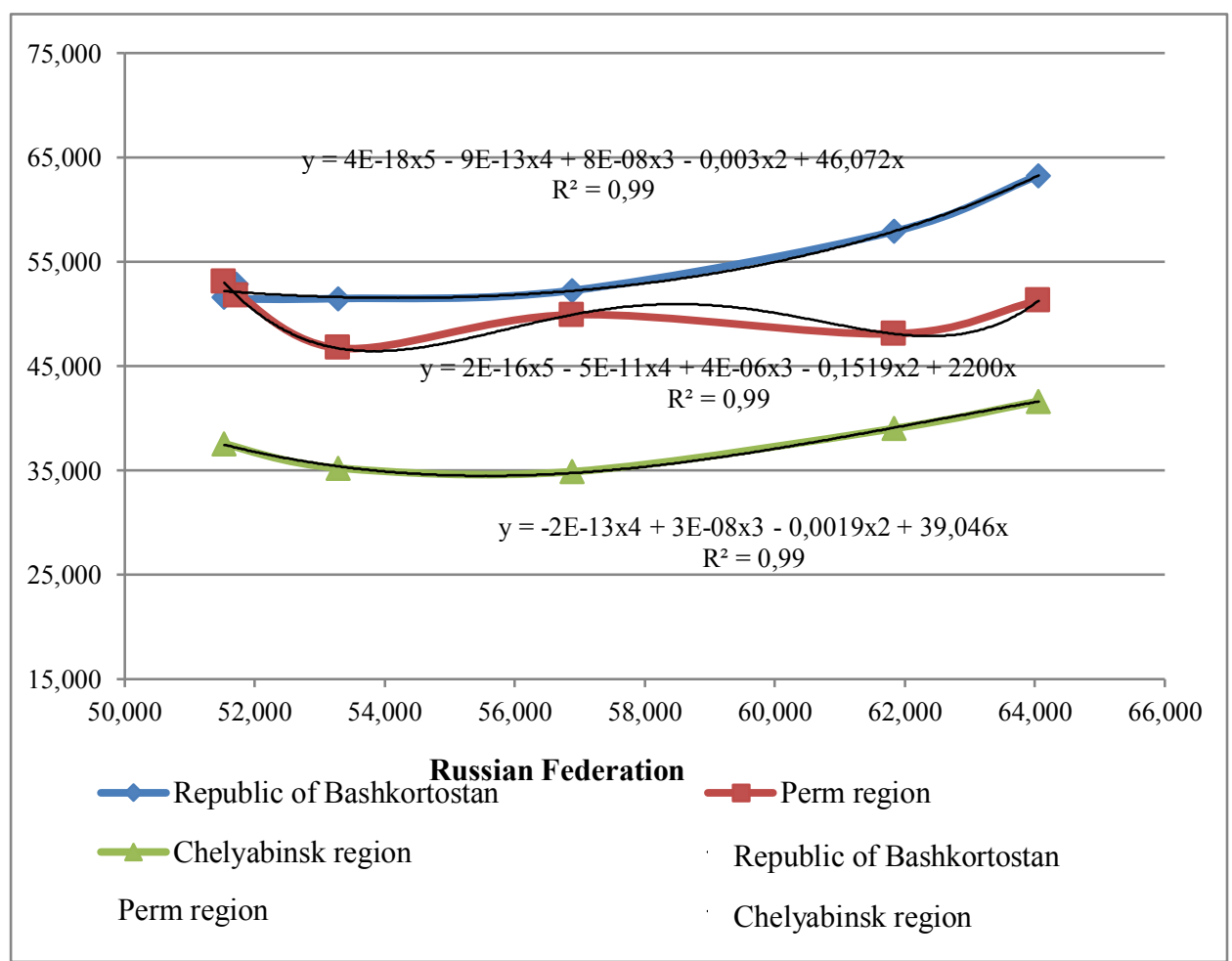

Fig. 4. Approximation of average prices in the housing market for 1 square meter of total area. 
Consider the ratio between the average per capita income of the population in the country and the average cost of housing (square meter) [9]. Based on this indicator, you can calculate the availability of real estate.

Table 1 shows that real estate is the least affordable for residents of Ufa and Moscow. The city of St. Petersburg lags slightly less behind Moscow in the anti-rating of housing affordability, in the prices of 2019, by 1983 in the USSR-0.8 units.

Table 1. Number of square meters of real estate that can be purchased on a monthly average per capita income.

\begin{tabular}{|c|c|c|c|c|c|}
\hline Regions & $\mathbf{2 0 1 5}$ & $\mathbf{2 0 1 6}$ & $\mathbf{2 0 1 7}$ & $\mathbf{2 0 1 8}$ & $\mathbf{2 0 1 9}$ \\
\hline $\begin{array}{c}\text { Russian } \\
\text { Federation }\end{array}$ & 0.70 & 0.68 & 0.65 & 0.63 & 0.64 \\
\hline $\begin{array}{c}\text { Republic of } \\
\text { Bashkortostan }\end{array}$ & 0.61 & 0.57 & 0.61 & 0.58 & 0.57 \\
\hline Perm Region & 0.64 & 0.64 & 0.62 & 0.69 & 0.69 \\
\hline $\begin{array}{c}\text { Chelyabinsk } \\
\text { Region }\end{array}$ & 0.75 & 0.75 & 0.74 & 0.70 & 0.67 \\
\hline
\end{tabular}

Analysis of housing prices shows that it is necessary to raise the issue of finding alternative methods of reducing prices for each region represented. For the construction of affordable and comfortable housing for the population, one approach would be to allocate land plots for construction within the framework of investment programs of the subject of the federation, setting free the construction company from additional costs for the purchase of land for development and for the construction of infrastructure facilities.

Table 2. Assessment of the impact of average prices on the housing market.

\begin{tabular}{|l|c|c|}
\hline $\begin{array}{c}\text { Region of the } \\
\text { country }\end{array}$ & $\begin{array}{c}\text { Correlation coefficient between the } \\
\text { average prices in the housing market } \\
\text { and the average per capita monetary } \\
\text { income of the population }\end{array}$ & $\begin{array}{c}\text { Correlation coefficient } \\
\text { between average prices in } \\
\text { the housing market and } \\
\text { the number of permanent } \\
\text { residents }\end{array}$ \\
\hline Russian Federation & 0.83 & 0.77 \\
\hline $\begin{array}{l}\text { Republic of } \\
\text { Bashkortostan }\end{array}$ & 0.84 & 0.69 \\
\hline Perm Region & 0.81 & -0.71 \\
\hline Chelyabinsk Region & 0.80 & 0.09 \\
\hline
\end{tabular}

In a similar way, we will try to establish the influence between average prices in the housing market and the average per capita monetary income of the population, as well as between the average prices on the housing market and the number of permanent residents on average for the year. We take the initial data from figure 4 and table 1, respectively. The results are presented in table 2.

\section{Conclusion}

Based on statistical calculations, it was found that the average market price of housing shows a strong correlation with the average per capita monetary income of the population and a relatively weak dependence on the number of permanent residents. The Republic of Bashkortostan shows the strongest correlation between the average market price of housing and monetary income, while the Chelyabinsk region shows the weakest correlation.

There is a strong correlation between average housing prices and the population in the Russian Federation, the weak one is in Perm Region. The article provides a statistical analysis of the impact of various factors on the price of housing in three regions of the 
Russian Federation. The main factor affecting the price of housing is the per capita income of the population.

\section{References}

1. M.I. Kameneckij, N.Y. Yas'kova, Construction economics 3, 2-13 (2009)

2. V.I. Barhatov, Bulletin of Chelyabinsk State University 1, 128-138 (2008)

3. D. Pletnev, E. Nikolaeva, E. Silova, E3S Web of Conferences 13014, 210 (2020) doi:10.1051/e3sconf/202021013014

4. V. Barkhatov, E3S Web of Conferences 15002, 210 (2020) doi:10.1051/e3sconf/202021015002

5. A. Kuznetsova, A. Selezneva, A. Askarov, A. Askarova, R. Gusmanov, Montenegrin Journal Of Economics 17(1), 175-183 (2021) DOI: 10.14254/1800-5845/2021.17-1.13.

6. A. Kuznetsova, A. Askarov, R. Gusmanov, A. Askarova, P. Pypłacz, Polish Journal of Management Studies 20(2), 345-357 (2019) 